\title{
Analisis Peran Pengusaha dalam Mengurangi Pengangguran Terbuka Perspektif Ekonomi Islam di Kota Bima (Studi Kasus HIPMI dan TDA Kota Bima)
}

\author{
Ismail $^{1^{*}}, W^{\prime}$ adarrahmah $^{2}$ \\ ${ }^{1,2)}$ Institut Agama Islam Muhammadiyah Bima \\ *Corresponding Author: ismailmuh.saleh17@gmail.com
}

\begin{abstract}
ABSTRAK - Penelitian ini bermaksud menganalisis peran pengusaha dalam mengurangi pengangguran terbuka perspektif Ekonomi Islam serta kendalanya. di Kota Bima yang bertujuan untuk mengetahui sejauh mana peran serta. Metode yang digunakan dalam penelitian ini adalah metode deskriptif kualitatif. Sedangkan teknik pengumpulan data yaitu observasi, wawancara dan dokumentasi. Jenis data penelitian yaitu data primer dan data sekunder. Kemudian data-data yang terkumpul dianalisis dan selanjutnya dilakukan uji keabsahan data dengan cara tringulasi data. Hasil penelitian ini menunjukkan bahwa peran pengusaha dalam mengurangi pengangguran terbuka di Kota Bima memiliki kontribusi real, dan perannya telah mengadopsi semangat Ekonomi Islam. Hal ini dapat dilihat dari pengusaha yang tergabung dalam HIPMI dan TDA memiliki bisnis yang berisiko dan cukup sukses dan mampu merekrut karyawan yang banyak seperti Yuank Cafe, Hotel La Ila, dan Fix La Luna, sehingga itu sedikit tidaknya mampu mengurangi angka pengangguran di Kota Bima. Sedangkan untuk kendalanya yaitu kurangnya penyuluhan tentang kedua organisasi tersebut, masyarakat berorintasi PNS, dan kurangnya jiwa wirausaha dalam diri masyarakat.
\end{abstract}

Kata Kunci - Peran; Pengusaha; Pengangguran; Ekonomi Islam

\section{PENDAHULUAN}

Pengangguran yang terjadi di Indonesia merupakan masalah yang kompleks dan bersifat multidimensi. Beberapa faktor penyebab yang bersifat eksternal antara lain kekurangan tersediaan lapangan kerja, rendahnya pertumbuhan kesempatan kerja jika dibandingkan dengan pertumbuhan angkatan kerja, urbanisasi, pertumbuhan ekonomi yang rendah, serta kesenjangan ekonomi. Kondisi ini diperparah lagi dengan jumlah investasi asing yang akan meninggalkan Indonesia dan pastinya setiap investasi asing yang keluar dari Indonesia akan berdampak pada pertambahan jumlah pengangguran. Kesalahan bukan terletak sepenuhnya di pihak investor dalam melakukan investasi, salah satu faktor penting yang dilihat adalah prospek dari investasi yang ditanam. Selain itu tingkat keamanan investasi tersebut sudah bukan hal yang asing jika daya tarik Indonesia sudah kalah dengan nagara-negara tetangganya. Tanggung jawab juga tidak dapat sepenuhnya diserahkan kepada pemerintah, sehebat apapun pemerintah jika persoalan sudah sedemikian parah penyelesaiannya juga akan memakan waktu yang tidak sebentar. ${ }^{1}$

Pengangguran dapat dibedakan menjadi dua macam. Pertama, Pengangguran Terbuka (Open Unemployment), yaitu tenaga kerja yang betul-betul tidak mempunyai pekerjaan. Pengangguran ini terjadi karena belum mendapat pekerjaan padahal telah berusaha secara maksimal dan ada juga yang karena malas mencari pekerjaan atau malas bekerja. Kedua, Pengangguran tertutup (Disguised Unemployment), yaitu pengangguran yang terjadi karena terlalu banyaknya tenaga kerja untuk satu unit pekerjaan padahal dengan mengurangi tenaga kerja tersebut sampai jumlah tertentu tetap tidak mengurangi jumlah produksi. Pengangguran

${ }^{1}$ Sukidjo, "Peran Pengusaha Dalam Mengatasi Pengangguran Di Indonesia", jurnal ekonomi,No. 1, Volume 1 (agustus, 2005) 85 
terselubung bisa juga terjadi karena seseorang yang bekerja tidak sesuai dengan bakat dan kemampuannya. ${ }^{2}$

Table 1. Tingkat Pengangguran Terbuka Menurut Data Badan Pusat Statistik (Bps) Kota Bima Tahun 2015-2019

\begin{tabular}{cc}
\hline Tahun & TPT (Persen) \\
\hline 2015 & 10.15 \\
2016 & 10.15 \\
2017 & 3.51 \\
2018 & 2.39 \\
2019 & 4.18 \\
\hline
\end{tabular}

Berdasarkan data pada tabel di atas tingkat pengangguran terbuka di kota bima pada tahun 2015 dan 2016 tidak mengalami perubahan, pada tahun 2017-2018 mengalami penurunan hingga tahun 2019 kembali menigkat. ${ }^{3}$

Menurut teori dan penelitian-penelitian terdahulu, pengangguran bisa terjadi dikarenakan beberapa faktor penyebab, salah satunya adalah jumlah penduduk. Ketika di suatu wilayah terdapat penambahan jumlah penduduk, maka akan terjadi penambahan jumlah angkatan kerja yang tersedia sehingga apabila jumlah lowongan kerja yang tersedia lebih sedikit maka akan ada pencari kerja yang tidak terserap di dunia kerja, oleh karena itu seharusnya pertambahan angkatan kerja juga diimbangi dengan pertambahan lapangan pekerjaan. ${ }^{4}$

Pengusaha menjadi salah satu alternatif cara untuk menyelesaikan masalah pengangguran dimana pemuda dibimbing untuk memiliki mental mandiri, agar dapat memiliki pemikiran out of the box terhadap situasi yang ada dan berani mengambil langkah dengan menciptakan lapangan pekerjaan bagi dirinya sendiri dan orang lain sehingga pada akhirnya dapat menggairahkan pertumbuhan perekonomian di negeri ini.

Dalam menjalankan misi besar bangsa ini maka pemerintah butuh mitra/organisasi kemasyarakatan yang mendukung dan mendongkrak dalam peningkatan ekonomi dan menumbuh kembangkan jiwa usaha (enterpreneur) kepada pemuda agar dapat membuka usaha sendiri dan lapangan pekerjaan untuk mengurangi pengangguran demi tercapainya pertumbuhan ekonomi.

Di Kota Bima ada dua organisasi nasional yang memiliki konsentrasi mengenai kewirausahaan dan berkontribusi dalam membangun serta mengurangi jumlah pengangguran terbuka di antaranya adalah Himpunan Pengusaha Muda Indonesia (HIPMI) dan Komunitas Tangan Di Atas (TDA).

Himpunan Pengusaha Muda Indonesia (HIPMI) adalah organisasi para pengusaha muda Indonesia yang bersatu dengan maksud dan tujuan mendorong, berperan serta dalam mengembangkan jiwa kewiraswastaan di kalangan generasi muda. Maksud dan tujuan organisasi ini dibentuk untuk membina, memajukan dan mengembangkan generasi muda pengusaha menjadi pengusaha yang profesional, kuat dan tangguh dalam sektor usaha yang ditekuni, melaksanakan program pemerintah dan turut mensukseskan proses pembangunan nasional maupun

${ }^{2}$ Ratih Probosiwi. "Pengangguran Dan Pengaruhnya Terhadap Tingkat Kemiskinan", Jurnal Pks, No. 2, Volume 15 (Juni 2016) 89

${ }^{3}$ Badan Pusat Statistik (Bps) Kota Bima, 23 maret 2020 Pres.2014, 67

${ }^{4}$ Mulyadi S. Ekonomi Sumber daya Manusia dalam perspektif Pembangunan, Jakarta: Rajawali 
daerah menuju kepada terciptanya masyarakat yang adil dan makmur, serta membentuk pengusaha nasional yang berwawasan kebangsaan, yang memiliki moral, etika dan bisnis serta mampu berdaya saing di pasaran internasional. ${ }^{5}$

Berdasarkan wawancara peneliti dengan mantan ketua Himpunan Pengusaha Muda Indonesia (HIPMI) Kota Bima bahwa HIPMI berkedudukan di Bima dan memiliki peran yang sangat besar dalam membantu mengurangi jumlah pengangguran. Organisasi ini bergerak di bidang perekonomian, bukan organisasi pemerintah, independen dan sasaran opresionalnya non politik. Tidak mencari keuntungan dan bersifat kekeluargaan. ${ }^{6}$

Selanjutnya Komunitas Tangan di Atas (TDA) adalah sebuah komunitas bergabungnya para wirausahawan. Di kota bima komunitas Tangan di Atas (TDA) didirikan pada tahun 2016. TDA mempunyai visi membentuk pengusahapengusaha tangguh dan sukses yang memiliki kontribusi positif bagi peradaban dan mempunyai misi menumbuh kembangkan semangat kewirausahaan. ${ }^{7}$

Selain itu semua, Ekonomi Islam tidak menghendaki praktek penanganan pengangguran mengedepankan unsur-unsur yang bertentangan dengan semangat Islam, baik yang dilakukan oleh pemerintah, Lembaga, maupun masyarakat. Semua praktek pembangunan hendaknya tidak mengabaikan aspek spiritual. Oleh karena itu artikel penelitian ini mengangkat tema; Anaisis Pengusaha dalam Mengurangi Pengangguran Terbuka Perspektik Ekonomi Islam Di Kota Bima.

\section{LANDASAN TEORI}

\section{Konsep Pengusaha}

\section{Pengertian Pengusaha}

Menurut ketentuan undang-undang nomor 13 tahun 2003 pasal 1 angka (5) menyebutkan bahwa pengusaha adalah:

1. Orang perseorangan, persekutuan, atau badan hukum yang menjalankan suatu perusahaan milik sendiri,

2. Orang perseorangan, persekutuan, atau badan hukum yang berdiri sendiri menjalankan perusahaan bukan miliknya,

3. Orang perseorangan, persekutuan, atau badan hukum yang berada di Indonesia mewakili perusahaan sebagaimana di maksud yang berkedudukan di luar wilayah Indonesia.

Pengusaha adalah seseorang yang menjalankan aktivitas usaha baik usaha jual beli, maupun usaha produksi yang mempunyai tujuan utama untuk memperoleh keuntungan dan menanggung resiko yang mungkin saja akan terjadi dalam aktivitas usahanya. 8

\section{Teori Pengusaha Menurut Para Ahli}

1. Arif F Hadipranata, pengusaha adalah sosok orang yang mengambil keputusan dalam sebuh perusahaan yang akan memberikan banyak keuntungan banyak

${ }^{5}$ Lola Imanda Harefa, "Analisis Program Kewirausahaan Himpunan Pengusaha Muda Indonsia (HIPMI) Dalam Meningkatkan Minat Berwirausaha Pemuda Di Kota Medan", ("skripsi", Sekolah Pascasarjan Universitas Sumatra Utara, Medan, 2018,), 6.

${ }^{6}$ Zulkifli Maman, Wawancara, Bima, Sabtu 18 Juli 2020 (7 juni 2020)

7 Profil TDA, Situs Resmi Komunitas TDA (Tangan Di Atas). http://www.tangandiatas.com.

8 Sukidzo, Peran pengusaha Dalam Mengatasi Pengangguran Di Indonesia, jurnal ekonomi, No 1, Volume 1, agustus 2005 
orang. Dan sosok itu menjadi sebuah inti dari pengusaha yang terlibat dalam perusahaan

2. Thomas $\mathrm{W}$ Zimmerer, pengusaha adalah penerapan sebuah inovasi dan juga kreativitas dalam memecahkan masalah menjadi sebuah peluang besar yang akan memanfaatkan banyak peluang yang akan memberikan keuntungan untuk banyak orang yang terlibat dalam sebuah perusahaan.

3. Andrew J Dubrin, pengusaha adalah orang yang mendirikan sebuah usaha dengan cara yang inovatif yang akan memberikan banyak keuntungan bagi banyak orang dan tentunya untuk orang yang menjalankan usaha.

4. Raimond, pengusaha adalah sebuah usaha untuk mensejahterakan diri dengan usaha yang kreatif dan inovatif yang akan membawa keuntungan dan akan menjadi sebuah proses dari kesejahteraan diri dengan sebuah usaha yang ada pada diri pengusaha.

5. Kasmir, pengusaha adalah sebuah tempat usaha seseorang yang berani mengambil segala resiko demi tercapainya sebuah maksud yang dia inginkan demi sebuah keuntungan.

\section{Manfaat Pengusaha}

Manfaat menjadi pengusaha tentu saja bisa melatih mental lebih kuat ketika berhadapan dengan tantangan yang banyak. Seorang pengusaha yang sudah berpengalaman tentu akan memiliki tingkat manajemen resiko dalam menjalankan usahanya. Akan lebih tahan terhadap kondisi apapun di lapangan.

\section{Hak dan Kewajiban Pengusaha}

1. Hak Pengusaha

Hak pengusaha adalah suatu yang harus diberikan kepada pengusaha sebagai konsekuensi adanya tenaga kerja yang bekerja padanya atau karena kedudukannya sebagai pengusaha. Adapun hak-hak pengusaha adalah sebagai berikut:

a) Pengusaha boleh menunda untuk pembayaran tunjangan sementara tidak mampu bekerja paling lama lima hari terhitung mulai dari kecelakaan kerja itu terjadi, jika buruh yang ditimpa kecelakaan tidak dengan perantara perusahaan atau kalau belum memperoleh surat keterangan dokter yang menerangkan, buruh tidak dapat bekerja karena di timpa kecelakaan (pasal 16 undang-undang no.12 tahun 1951).

b) Berhak menetapkan mulainya istirahat tahunan dengan memperhatikan kepentingan buruh (pasal 5 ayat (1) PP No.21 tahun 1954).

c) Dapat memperhitungkan upah buruh selama sakit dengan suatu pembayaran yang diterima oleh buruh tersebut yang timbul dari suatu perundang-undangan/ peraturan perusahaan/suatu dana yang menyelenggarakan jaminan sosial ataupun suatu pertanggungan (pasal 7 PP No.8 tahun 1981).

d) Dapat menjatuhkan denda atas pelanggaran suatu hal apabila hal itu diatur secara tegas dalam suatu perjanjian tertulis atau peraturan perusahaan (pasal 20 ayat (1) PP No 8 tahun 1981)

e) Dapat meminta ganti rugi kepada buruh, bila mana terjadi kerusakan barang atau kerugian lainnya baik milik perusahaan maupun milik pihak ketiga oleh buruh karena kesengajaan atau kelalaiannya (pasal 23 ayat (1) PP No.8 Tahun 1981). 
2. Kewajiban Pengusaha

Kewajiban pengusaha adalah suatu prestasi yang harus dilakukan oleh pengusaha, bagi kepentingan tenaga kerjanya. Adapun kewajiban pengusaha itu sebagai berikut:

a) Kewajiban memberikan istirahat atau cuti.

Cuti adalah pihak majikan/pengusaha diwajibkan untuk memberikan istirahat tahunan secara teratur.

b) Kewajiban mengurus perawatan dan pengobatan.

Majikan/pengusaha wajib mengurus perawatan atau pengobatan bagi pekerja yang sakit atau yang mengalami kecelakaan kerja.

c) Kewajiban memberikan surat keterangan.

Pengusaha wajib memberikan surat keterangan yang diberi tanggal dan dibubuhi tanda tangan. Dalam surat keterangan tersebut dijelaskan mengenai sifat pekerjaan yang dilakukan, lamanya hubungan kerja (masa kerja).

d) Kewajiban membayar upah

Dalam hubungan kerja kewajiban utama bagi seorang pengusaha adalah membayar upah kepada pekerjanya tepat waktu. Upah adalah suatu penerimaan sebagai imbalan dari pengusaha kepada buruh atas prestasi berupa pekerjaan atau jasa yang telah atau akan dilakukan oleh pekerja dan dinyatakan atau dinilai dengan uang.

\section{Konsep Pengangguran \\ Pengertian Pengangguran}

Pengangguran menurut Hartini dan G. Kartasapoetra, adalah suatu kenyataan apabila orang atau tenaga kerja tidak mendapatkan pekerjaan. Sedangkan menurut Suroto, Pengangguran adalah kejadian atau keadaan orang sedang menganggur.

Dalam pengertian makro ekonomi pengangguran adalah sebagian dari angkatan kerja yang sedang tidak mempunyai pekerjaan. Dalam pengertian mikro pengangguran adalah keadaan seorang yang mampu dan mau melakukan pekerjaan akan tetapi sedang tidak mempunyai pekerjaan. Lebih lanjut Suroto menjelaskan pengertian penganggur adalah orang yang mampu bekerja, tidak mempunyai pekerjaan, dan ingin bekerja atau baik secara aktif, maupun pasif mencari pekerjaan. Tingkat Pengangguran Untuk mengukur seberapa besar pengangguran yang ada di suatu wilayah digunakan konsep mengenai mengenai tingkat pengangguran. ${ }^{9}$

\section{Macam-Macam Pengangguran}

Pengangguran dapat digolongkan menjadi beberapa jenis berdasarkan beberapa faktor yang mempengaruhinya. Menurut Mulyadi Subri (2003:60-61) macam-macam pengangguran antara lain:

1. Pengangguran terbuka (open unemployment): bagian dari angkatan kerja yang sekarang ini tidak bekerja dan sedang aktif mencari pekerjaan.

2. Setengah menganggur (underemployment): perbedaan antara jumlah pekerjaan yang betul dikerjakan seseorang dalam pekerjaannya dengan jumlah pekerjaan yang secara normal mampu dan ingin dikerjakannya.

\footnotetext{
${ }^{9}$ Amiruddin Idris, Ekonomi Publik, (Yogyakarta: Deepublish, 2016), hal. 120
} 
3. Setengah menganggur yang kentara (visible underemployment): jika seseorang bekerja tidak tetap (part time) diluar keinginannya sendiri, atau bekerja dalam waktu yang lebih pendek dari biasanya.

4. Setengah menganggur yang tidak kentara (invisible underemployment): jika seseorang bekerja secara penuh (full time) tetapi pekerjaannya itu dianggap tidak mencukupi, karena pendapatannya yang terlalu rendah atau pekerjaan tersebut tidak memungkinkan ia untuk mengembangkan seluruh keahliannya.

5. Pengangguran tidak kentara (disnguised unemployment): Dalam angkatan kerja mereka dimasukkan dalam kegiatan bekerja, tetapi sebetulnya mereka adalah pengangguran jika dilihat dari segi produktivitasnya.

6. Pengangguran friksional: pengangguran yang terjadi akibat pindahnya seseorang dari suatu pekerjaan ke pekerjaan lain, dan akibatnya harus mempunyai tenggang waktu dan berstatus sebagai penganggur sebelum mendapatkan pekerjaan yang lain tersebut.

7. Pengangguran struktural: pengangguran yang disebabkan karena ketidakcocokan antara struktur para pencari kerja sehubungan dengan keterampilan, bidang keahlian, maupun daerah lokasinya dengan struktur permintaan tenaga kerja yang belum terisi. ${ }^{10}$

Sedangkan macam-macam pengangguran menurut Suroto adalah :

1. Pengangguran peralihan. Pengangguran peralihan disebabkan karena pencari kerja tidak mengetahui bahwa ada lowongan yang sesuai dengan kualifikasi dan keinginan yang dimilikinya. Atau di pihak lain pengusaha yang mencari tenaga tidak mengetahui bahwa ada pencari kerja yang memenuhi syarat tersedia baginya.

2. Pengangguran musiman. Pengangguran musiman disebabkan oleh fluktuasi kegiatan produksi dan distribusi barang dan jasa yang dipengaruhi oleh musim. Ada pola musiman yang disebabkan oleh faktor iklim dan oleh kebiasaan masyarakat.

3. Pengangguran konjungtural. Pengangguran konjungtural timbul karena penurunan kegiatan ekonomi. Kekurangan permintaan efektif mengenai barang dab jasa menyebabkan penurunan kegiatan produksi dan distribusi perusahaan. Akibatnya terjadi pengurangan penggunaan tenaga kerja.

4. Pengangguran teknologi. Pengangguran ini disebabkan karena adanya perubahan teknologi produksi. Perubahan ini menyangkut proses pekerjaan, jenis bahan yang digunakan, tingkat produktivitas kerja, dan penggunaan mesinmesin yang hemat tenaga kerja.

5. Pengangguran structural. Pengangguran ini disebabkan oleh perubahan struktur pasar barang dan disebabkan oleh struktur perekonomian yang belum maju, kurang mampu menciptakan cukup lapangan kerja produktif dan remuneratif bagi seluruh angkatan kerjanya.

6. Pengangguran khusus. Pengangguran ini biasanya memerlukan penanganan khusus. Misalnya adalah penyandang cacat dan pengungsi.

7. Pengangguran muda. Pengangguran ini disebabkan oleh pemuda-pemuda yang belum memiliki keterampilan dan pengalaman kerja yang cukup sehingga sulit untuk memperoleh pekerjaan.

10 Sukidzo, Peran pengusaha Dalam Mengatasi Pengangguran Di Indonesia, jurnal ekonomi, No 1, Volume 1, agustus 2005 
8. Pengangguran tua. Pengangguran ini biasanya diderita oleh orang-orang yang karena sesuatu sebab tidak dapat menjalani kariernya sampai usia cukup tua untuk mengundurkan diri dari dunia pekerjaan.

9. Pengangguran wanita. Disebabkan karena penghargaan terhadap peranan wanita dalam kehidupan ekonomi yang rendah sehingga yang lebih banyak digunakan adalah tenaga kerja laki-laki.

10. Pengangguran yang disebabkan oleh isolasi geografis. Pengangguran ini dialami oleh masyarakat yang tinggal dalam wilayah yang jauh terpencil dari pusat kegiatan ekonom, yang menjadi pusat pasar kerja.

\section{Dampak Pengangguran}

Pengangguran yang terjadi di dalam suatu perekonomian dapat membawa dampak dan akibat buruk, baik terhadap perekonomian maupun individu dan masyarakat. Setiap negara selalu berusaha agar tingkat kemakmuran masyarakatnya dapat dimaksimumkan dan perekonomian selalu mencapai pertumbuhan ekonomi yang berkelanjutan, tingkat pengangguran yang relative tinggi tidak memungkinkan masyarakat mencapai tujuan, hal ini dapat dilihat dengan jelas dari berbagai akibat buruk yang bersifat ekonomi yang ditimbulkan oleh masalah pengangguran. Akibat-akibat buruk pengangguran terhadap perekonomian adalah:

1. Pengangguran menyebabkan masyarakat tidak dapat memaksimumkan tingkat kesehjateraan yang mungkin dicapai dan menyebabkan pertumbuhan produk (output) yang dicapai lebih rendah, keadaan ini berarti tingkat kemakmuran masyarakat yang dicapai lebih rendah dari tingkat yang akan dicapai.

2. Pengangguran menyebabkan pendapatan pajak pemerintah (tax revenue) berkurang. Pengangguran disebabkan oleh rendahnya tingkat kegiatan ekonomi, pada gilirannya akan menyebabkan pendapatan pajak yang mungkin diperoleh pemerintah akan menjadi semakin sedikit, dengan demikian tingkat pengangguran yang tinggi akan mengurangi kemampuan pemerintah dalam menjalankan berbagai kegiatan pembangunan.

3. Pengangguran dapat menyebabkan kehilangan atau berkurangnya keterampilan, keterampilan dalam mengerjakan sesuatu pekerjaan hanya dapat dipertahankan apabila keterampilan tersebut digunakan dalam praktik Pengangguran dalam kurun waktu yang lama menyebabkan tingkat keterampilan (skills) pekerja semakin merosot.

4. Pengangguran menyebabkan kehilangan mata pencaharian dan pendapatan. Di negara-negara maju, para penganggur memperoleh tunjangan (bantuan keuangan) dari badan asuransi pengangguran, dan oleh sebab itu, mereka masih mempunyai pendapatan untuk membiayai kehidupannya dan keluargannya. Mereka tidak perlu bergantung kepada tabungan mereka atau bantuan orang lain. Sebaliknnya, di negara - negara berkembang tidak terdapat program asuransi pengangguran, dan karenanya, kehidupan penganggur harus dibiayai oleh tabungan masa lalu atau pinjaman/bantuan keluarga dan temanteman keadaan ini potensial bisa mengakibatkan pertengkaran dan kehidupan keluarga yang tidak harmonis.

5. Pengangguran yang tinggi akan menghambat, dalam arti tidak akan menggalakkan pertumbuhan ekonomi. Pengangguran menimbulkan dua akibat buruk kepada kegiatan sektor suasta. Pertama, pengangguran tenaga kerja biasanya akan diikuti oleh kelebihan kapasitas mesin-mesin perusahaan. 
Keadaan ini jelas tidak akan mendorong perusahaan untuk melakukan investasi dimasa yang akan datang. Kedua, pegangguran yang timbul sebagai akaibat dari kelesuan kegiatan perusahaan menyebabkan keuntungan berkurang. Keuntungan yang rendah mengurangi keinginan perusahaan untuk melakukan investasi. Kedua hal tersebut jelas tidak akan menggalakkan pertumbuhan ekonomi dimasa yang akan datang. ${ }^{11}$

\section{Pengusaha dalam Ekonomi Islam}

Kesejahteraan adalah tujuan utama bagi daerah maupun negara yang dapat dicapai melalui program-program pendukung. ${ }^{12}$ Salah satunya adalah dengan cara menanamkan jiwa produktif (pengusaha) kepada rakyat. Pengusaha dalam Ekonomi Islam adalah implementasi dari fungsi manusia sebagai khalifah yang berperan dalam memakmurkan bumi. Tentunya, melalui kaidah dan semangat Islam. Kaidah dan semangat tersebut seperti yang di uraikan sebagai berikut:

\section{Motivasi Islam tentang Semangat Kerja Keras dan Kemandirian ${ }^{13}$}

1. Amal yang paling baik adalah pekerjaan yang dilakukan dengan cucuran keringat, "amalurrajuli biyadihi" (HR. Abu Dawud)

2. Tangan di atas lebih baik tangan di bawah, "al yad 'ulya khairun min al yad al sulfa" (HR. Bukhari dan Muslim)

3. Dalam Al-quran:

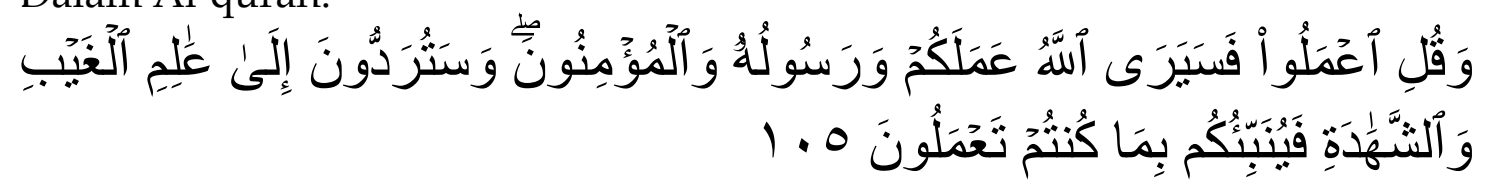

Terjemahan: Dan Katakanlah: "Bekerjalah kamu, maka Allah dan Rasul-Nya serta orang-orang mukmin akan melihat pekerjaanmu itu, dan kamu akan dikembalikan kepada (Allah) Yang Mengetahui akan yang ghaib dan yang nyata, lalu diberitakan-Nya kepada kamu apa yang telah kamu kerjakan. (At-Taubah:105)

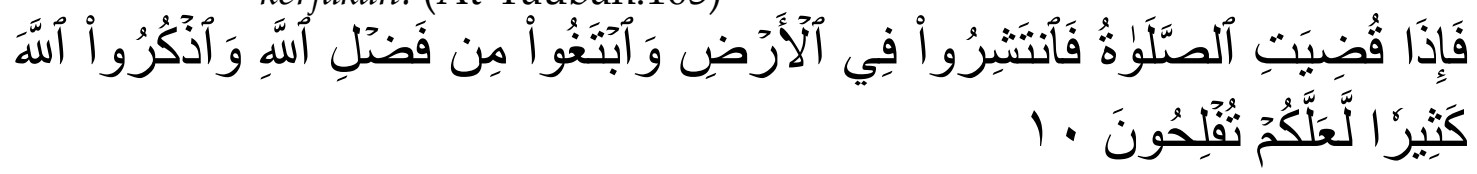

Terjemahan: Apabila telah ditunaikan shalat, maka bertebaranlah kamu di muka bumi; dan carilah karunia Allah dan ingatlah Allah banyak-banyak supaya kamu beruntung. (QS: al-Jumu'ah: 10)

\section{Landasan Moral dalam Usaha14}

1. Merasa Terpantau

Pengusaha menyadari bahwa sesungguhnya usaha-usaha yang dilakukan dalam pantauan dan pengawasan Allah SWT. Kesadaran karena merasa terpantau ini akan memberikan dorongan untuk mengontrol diri (self control) dari aktifitas menyimpang.

2. Jujur

Jujur bermakna kesucian nurani yang dapat memberikan jaminan spiritual terhadap kebenaran yang diperbuat, ketepatan bekerja, dapat dipercaya, serta jauh dari perbuatan dusta.

11 Ibid., h. 18

12 Ismail, Kemiskinan Perspektif Ekonomi Islam, Jurnal Ekonomi Syariah (J-ESA), Volume 3, Nomor 1, Juni 2020. h. 123

13 Rusydi Ananda \& Tien Rafida, Pengantar Kewirausahaan: Rekayasa Akademik Melahirkan Enterpreneurship, (Medan: Perdana Publishing, 2016), h. 218

${ }^{14} \mathrm{Ibid}, \mathrm{h} .233-234$ 
3. Amanah

Kepercayaan yang biasanya diberikan orang-orang kepada orang lain bermodalkan kejujuran. Kepercayaan yang demikian adalah suatu penghargaan bagi orang tersebut karena kejujurannya.

4. Taqwa

Taqwa dapat dimaknai sebagai sikap waspada dalam menjaga diri dari kemurkaan Allah melalui jalan tidak menganiaya dirinya sendiri dan orang lain.

\section{METODELOGI PENELITIAN}

\section{Jenis Penelitian}

Dalam penelitian ini peneliti menggunakan pendekatan deskriptif kualitatif yaitu dengan melakukan penelitian yang menghasilkan data deskriptif berupa katakata atau laporan terperinci dari pandangan responden..$^{15}$ Dengan demikian metode kualitatif dalam penulisan ini adalah untuk membuat deskripsi, gambaran atau tulisan secara sistematis, dan akurat mengenai fakta-fakta serta hubungan antara fenomena-fenomena yang di selidiki kemudian di analisa dan diinterpretasikan dengan tepat. Untuk itu dalam penelitian ini, penulis mengatakan survey lapangan merupakan hal yang dilakukan untuk memperoleh informasi sebanyak-banyaknya yang berkaitan dengan peran pengusaha dalam mengurangi pengangguran terbuka di kota Bima.

\section{Sumber Data Dan Tekhnik Pengumpulan Data}

Sumber data terdiri dari data Primer dan sekunder. Data primer adalah sumber data yang langsung memberikan data kepada pengumpul data. ${ }^{16}$ Data ini diperoleh langsung dari responden berdasarkan wawancara yang dilakukan oleh peneliti yang berlangsung pada objeknya. ${ }^{17}$ Berdasarkan pendapat tersebut, maka objek penelitian ini adalah anggota HIPMI (Himpunan Pengusaha Muda Indonesia) dan komunitas TDA (Tangan Di Atas) kota Bima. Dengan memperoleh data-data secara langsung dalam bentuk wawancara, dokumentasi dan observasi. Sedangkan sumber data sekunder adalah sumber yang tidak langsung memberikan data kepada pengumpul data misalnya lewat orang lain atau lewat dokumen. Data sekunder merupakan data yang diperoleh dari literatur dan studi pustaka yang mendukung data utama tentang peran pengusaha dalam mengurangi pengangguran terbuka di kota Bima. Data yang diperoleh berupa dokumen, arsip informasi, fakta tertulis yang berada pada sumber penelitian yaitu pada HIPMI (Himpunan Pengusaha Muda Indonesia) dan komunitas TDA (Tangan Di Atas) kota Bima yang berkaitan dengan judul penelitian ini.

\section{Teknik pengumpulan data}

Teknik pengumpulan data merupakan langkah yang paling strategis dalam penelitian, karena tujuan utama penelitian adalah mendapatkan data, tanpa mengetahui tekhnik pengumpulan data, maka peneliti tidak akan mendapatkan data yang memenuhi standar data yang ditetapkan. Dalam melakukan pengumpulan data, penulis menggunakan beberapa pedoman seperti Observasi, wawancara, dan dokumentasi.

15 Juliansyah Noor, Metodelogi Penelitian, (Jakarta: Kencana, 2011), 34.

16 Sugiyono, Metode Penelitian Kuantitatif Kualitatif Dan RED, (Bandung: alfabeta,Cv, 2011), 


\section{Teknis Analisis Data}

Analisa data adalah proses mencari dan menyusun secara sistematis data yang diperoleh dari hasil wawancara, catatan lapangan, dan dokumentasi, dengan cara mengorganisasikan data kedalam kategori, menjabarkan kedalam unit-unit, melakukan sintesa, menyusun kedalam pola, memilih mana yang penting dan akan dipelajari, dan membuat kesimpulan sehingga mudah dipahami oleh diri sendiri maupun orang lain.

Annalisa yang digunakan dalam penelitian ini adalah bersifat induktif. Menurut sutrisno, bahwa berfikir induktif berangkat dari fakta-fakta, peristiwa-peristiwa yang konkrit kemudian dari fakta-fakta atau peristiwa khusus itu ditarik beberapa generalisasi yang bersifat umum. Peneliti menggunakan metode induktif untuk menarik kesimpulan terhadap hal-hal yang telah terkumpul melalui observasi, wawancara dan dokumentasi.

\section{HASIL DAN PEMBAHASAN}

\section{Peran Pengusaha Dalam Mengurangi Pengangguran Terbuka di Kota Bima Mendirikan Hotel}

Berdasarkan hasil wawancara dengan mantan ketua Himpunan Pengusaha Muda Indonesia (HIPMI) Kota Bima bapak Zulkifli Maman lokasi Hotel La Ila Kota Bima mengatakan bahwa Salah satu bentuk peran real HIPMI dalam mengurangi pengangguran terbuka di Kota Bima adalah dengan mendirikan sebuah usaha. Salah satu usaha yang didirikan oleh bapak Zulkifli Maman yaitu perhotelan. Bapak Zulkifli Maman merupakan pemilik Hotel La Ila Graha Kota Bima yang sampai sekarang masih menjadi salah satu hotel yang diminati dikota bima. Jumlah karyawan yang bekerja di hotel tersebut sebanyak 10 orang.

Bapak Zulkifli Maman juga menegaskan yang dimaksud pengusaha adalah semangat, sikap perilaku, dan kemampuan seseorang dalam menangani usaha dan atau kegiatan yang mengarah pada upaya mencari, menciptakan, menerapkan acara kerja, tekhnologi dan produk baru dengan meningkatkan efisiensi dalam rangka memberikan pelayanan yang lebih baik dan atau memperoleh keuntungan yang lebih besar. Dengan kata lain untuk mengatasi pengangguran perlu ditanamkan sikap mental wirausaha sehingga pada diri mereka akan terjangkit ciri dan watak wirausaha yang akan mendasari setiap perilaku kehidupannya. ${ }^{18}$

\section{Mendirikan Kafe}

Berdasarkan hasil wawancara dengan Ketua Komunitas Tangan Diatas (TDA) Kota Bima, Bapak Anang Zaini lokasi bertempat di JL. RA Kartini 9 Paruga Kota Bima pada pukul 16:00 Wib, Fix La Luna, Cafe tersebut dimiliki oleh pengusaha muda kota bima yaitu Fadli Ibanes. Bapak Anang Zaini merupakan salah satu anggota komunitas Tangan di Atas yang terbilang sukses di dunia bisni. Dari kepiawaian dan ide kreatifnya dalam mengembangkan kafe yang bernuansa modern tersebut sehingga mengundang minat masyarakat untuk berkunjung di tempat tersebut, ia berhasil merekrut 40 karyawan untuk bekerja di kafe yang terbilang masih baru tersebut. Hal itu menunjukkan bahwa para pengusaha yang tergabung dalam komunitas Tangan di Atas memiliki kontribusi real dalam mengurangi jumlah pengangguran di Kota Bima. ${ }^{19}$

\footnotetext{
${ }^{18}$ zulkifli maman, wawancara, Kota Bima, 27 agustus 2020

${ }^{19}$ Fadli, wawancara, Kota Bima 03 agustus 2020
} 


\section{Mendirikan Laki Lucky Barbershop}

Laki Lucky Barbershop merupakan usaha yang digandrungi oleh salah satu anggota TDA Bapak Herdi, selain barbershop bapak Herdi juga memiliki usaha salon muslimah dan rumah makan, dari ketiga bisnis yang digelutinya sehingga memiliki karyawan sejumlah 20 orang. ${ }^{20}$

\section{Mendirikan Yuank Cafe}

Yuank Cafe merupakan kafe yang dimiliki oleh seorang pengusaha muda yang sukses di bisnis kuliner Pak Anang Zaini yang juga merupakan ketua komunitas Tangan di Atas. Yuank Cafe bertempat di JL. RA Kartini 9 Paruga Kota Bima. Dari kegigihan dan kerja kerasnya bapak Anang berhasil mendirikan cabang baru Yuank Cafe yang terletak di Penaraga Kota Bima dan Tolomundu. Sampai saat ini bapak Anang Zaini memiliki 30 karyawan di tiga cabang. Itu menunjukan bahwa pengusaha di Kota Bima memiliki peran dalam mengurangi pengangguran terbuka dikota bima. ${ }^{21}$

Berdasarkan hasil wawancara dengan anggota Komunitas Tangan Diatas (TDA) Kota Bima Bapak Herdi, salah satu upaya TDA selain membuka lowongan pekerjaan untuk para penganggur, mereka juga mengadakan seminar kewirausahaan dan mengundang seluruh mahasiswa maupun sarjana yang menganggur dalam rangka memberikan pemahaman agar para penganggur sebaiknya memiliki ciri dan watak pengusaha sebagai berikut:

1. Percaya diri, dalam arti para pencari kerja sebaiknya memiliki optimisme yang tinggi bahwa mereka memiliki kemampuan yang dapat disumbangkan dalam proses produksi, sehingga tidak akan bergantung kepada pihak lain. Dengan adanya individualitas dan kepercayaan yang tinggi mereka berani mencoba untuk menciptakan usaha sendiri sesuai dengan kemampua $n$ dan keterampilan yang dimilikinya.

2. Berorientasi pada tugas dan hasil dalam arti dalam menjalankan kegiatan selalu berusaha mengejar prestasi tertinggi, berorientasi pada laba atau keunggulan yang lain. Untuk dapat mencapai hal tersebut mereka harus menyadari perlunya kerja keras, memiliki dorongan yang kuat, ulet, tekun, energik serta inisiatif. Dengan kata lain mereka perlu mengembangkan motif berprestasi.

3. Pengambil risiko, dalam arti mereka lebih senang bekerja pada kegiatan. yang memiliki risiko pada tingkat sedang sehingga mendorong pengembangan kreativitas dan inisiatifnya.

4. Kepemimpinan, dalam arti mereka mampu bertindak sebagai pemimpin yang mengutamakan leadership dari pada manajerialnya. Kepemimpinan (leadership) akan cenderung mengembangkan sikap bekerja secara kolektif, menempatkan karyawan sebagai mitra kerja sehingga tercipta iklim kerja yang kondusif. Sebaliknya kepemimpinan managerial cenderung mendudukkan diri sebagai "boss" yang senang memerintah, merasa memiliki iklim kerja yang kondusif. Sebaliknya kepemimpinan managerial cenderung mendudukkan diri sebagai "boss" yang senang memerintah, merasa memiliki status yang lebih tinggi sehingga menempatkan karyawan sebagai sejajar dengan faktor produksi lainnya.

${ }^{20}$ Herdi, wawancara, Kota Bima 28 agustus 2020

${ }^{21}$ Anang Zaini, Wawancara, Kota Bima 7 juli 2020 
5. Keorisinilan, dalam arti produk atau kegiatan yang dilakukan tidak hanya meniru yang telah ada, melainkan mereka menciptakan sesuatu yang berbeda dengan yang lain, yang. merupakan ciri khas yang dapat diunggulkan. Untuk menciptakan orisinalitas mereka harus kreatif dan inovatif, bersifat fleksibel, memiliki pengetahuan luas serta memiliki banyak sumber.

6. Berorientasi ke masa depan, dalam arti dapat memprediksl apa yang diperlukan di masa depan yang pada saat kini belum banyak dllakukan. Untuk itu, mereka sebaiknya mampu melakukan analisis tentang kekuatan, kelemahan, peluang serta tantangan, yang lebih dlkenal dengan analisis SWOT. ${ }^{22}$

\section{Kendala Yang Dihadapi Oleh Pengusaha dalam Mengurangi Pengangguran Terbuka di Kota Bima}

\section{Orientasi PNS}

Berdasarkan hasil wawancara dengan mantan ketua Himpunan Pengusaha Muda Indonesia (HIPMI) Kota Bima bapak Zulkifli Maman lokasi Hotel La Ila Kota Bima, Mahasiswa lebih memilih mencari kerja daripada menciptakan lapangan kerja, upaya pemerintah untuk mengurangi pengangguran dengan merekrut calon Pegawai Negeri Sipil (PNS) tentu tidak cukup dalam menyediakan lapangan kerja bagi lulusan universitas. Menumbuhkan jiwa kewirausahaan pada mahasiswa dipercaya sebagai alternatif jalan keluar untuk mengurangi tingkat pengangguran karena para sarjana diharapkan dapat menjadi wirausahawan muda terdidik yang mampu merintis usahanya sendiri.

\section{Kurangnya Jiwa Berwirausaha}

Berdasarkan hasil wawancara dengan Ketua Komunitas Tangan Diatas (TDA) Kota Bima, Bapak Anang Zaini lokasi bertempat di JL. RA Kartini 9 Paruga Kota Bima pada pukul 16:00 WIB, Kurangnya penyuluhan di masyarakat tentang hubungannya terhadap perekonomian dan pentingnya berjiwa wirausaha sehingga pemikiran para sarjana muda cenderung instan dan memilih pekerjaan kantoran karena menganggap menjadi seorang pengusaha itu harus memulai dari nol. ${ }^{23}$

Berdasarkan hasil wawancara dengan staf seksi sosial mbak Hilmi lokasi kantor BPS Kota Bima pada pukul 16:30 Wib, mengatakan bahwa dari hasil data yang diperoleh badan pusat statistik mulai dari tahun 2015-2019 menunjukkan bahwa sejak adanya banyak pengusaha dibima khususnya HIPMI dan TDA mempunyai pengaruh yang signifikan dalam membantu mengurangi jumlah pengangguran dikota bima karna jika diperkirakan hampir ratusan penganggur direkrut oleh pengusaha-pengusaha tersebut untuk dijadikan karyawan. ${ }^{24}$

\section{PEMBAHASAN}

\section{Peran Pengusaha dalam Mengurangi Penganguran Terbuka di Kota Bima}

Pengangguran yang terjadi di dalam suatu perekonomian dapat membawa dampak dan akibat buruk, baik terhadap perekonomian maupun individu dan masyarakat, setiap Negara selalu berusaha agar tingkat kemakmuran masyarakatnya dapat dimaksimumkan dan perekonomian selalu mencapai pertumbuhan ekonomi yang berkelanjutan, tingkat pengangguran yang relative tinggi tidak memungkinkan masyarakat mencapai tujuan, hal ini dapat dilihat

\footnotetext{
${ }^{22}$ Anang zaini, wawancara, Kota Bima 7 juli 2020

${ }^{23} \mathrm{Ibid}$., h.43

${ }^{24}$ Hilmi, Wawancara, Kota Bima, 24 n0vember 2020
} 
dengan jelas dari berbagai akibat buruk yang bersifat ekonomi yang ditimbulkan oleh masalah pengangguran. ${ }^{25}$

Pengusaha memiliki peran yang sangat besar dalam rangka meminimalisir angka pengangguran di Kota Bima. Salah satu peran pengusaha adalah menciptakan lapangan kerja serta merekrut karyawan sesuai dengan skill untuk dibimbing dan dibina agar menjadi pekerja yang professional. Pengusaha adalah sosok orang yang mengambil keputusan dalam sebuah perusahaan yang akan memberikan banyak keuntungan banyak orang. Dan sosok itu menjadi sebuah inti dari pengusaha yang terlibat dalam perusahaan.

Manfaat menjadi pengusaha tentu saja bisa melatih mental lebih kuat ketika berhadapan dengan tantangan yang banyak. Seorang pengusaha yang sudah berpengalaman tentu akan memiliki tingkat memanajemen resiko dalam menjalankan usahanya. Akan lebih tahan terhadap kondisi apapun di lapangan.

Adapun pola pengembangan pengusaha dapat dikelompokkan menjadi dua macam yakni:

1. Pola Pengembangan Tradisional, yakni pola yang hampir tidak disadari sebagai program pengembangan kewirausahaan. Termasuk dalam pola pengembangan trasisional antara lain Magang eara Minang, Wirausaha eara China, Magang pola pedagang keliling, dan magang dengan pola usaha angkutan dan sektor jasa.

2. Pola Pengembangan Modern, yakni pola yang dirancang secara sadar sebagai program pengembangan. Termasuk dalam pola ini, antara lain Pola Inkubator, pola Franchaise, Pola Kemitraari Usaha Kecil, Pola Program Usaha Mandiri dan Kewirausahaan, Pola Penumbuhan Kewirausahaan Program Pemuda Mandiri Tenaga Kerja Mandiri yang dilaksanakan oleh Departemen Tenaga Kerja dan Kantor Menteri Pemuda dan Olahraga, serta Pola Program Pengembangan Budaya Kewirausahaan yang dikembangkan oleh Pendidikan Tinggi. ${ }^{26}$.

Hasil wawancara menjelaskan bahwa salah satu bentuk peran real HIPMI dalam mengurangi pengangguran terbuka di Kota Bima adalah dengan mendirikan sebuah usaha. Usaha-usaha yang di dirikan antara lain mendirikan hotel, café, dan jasa barbershop. Hal yang dilakukan oleh HIPMI adalah implementasi dari semangat kerja yang diharapkan dan dicita-citakan Ekonomi Islam.

"Amal yang paling baik adalah pekerjaan yang dilakukan dengan cucuran keringat, "amalurrajuli biyadihi" (HR. Abu Dawud)

Dimana, usaha-usaha yang dilakukan tergolong rumit (mendirikan hotel, café, dan jasa babershop), akan tetapi mereka mampu menekuninya dan berkontribusi untuk orang lain. Selain itu, semangat usaha yang digeluti itu sejalan dengan keinginan Allah SWT. melalui surah at-Taubah ayat 105.

\section{Kendala Yang Dihadapi Pengusaha Dalam Mengurangi Pengangguran Terbuka di Kota Bima}

Menurut Hubeis, permasalahan umum yang biasanya terjadi pada UMKM yaitu:

1. Kesulitan Pemasaran

Pemasaran sering dianggap sebagai salah satu kendala yang kritis bagi perkembangan UMKM. Dari hasil studi yang dilakukan oleh James dan

${ }^{25}$ Sukidzo, Peran Kewirausahaan Dalam Mengatasi Pengangguran Di Indonesia, jurnal ekonomi, No 1, Volume 1, agustus 2005

${ }^{26}$ Fadli, wawancara, 20 juli 2020 
Akrasanee (1988) di sejumlah Negara ASEAN, menyimpulkan UMKM tidak melakukan perbaikan yang cukup di semua aspek yang terkait dengan pemasaran seperti peningkatan kualitas produk dan kegiatan promosi. Akibatnya, sulit sekali bagi UMKM untuk dapat turut berpartisipasi dalam era perdagangan bebas. Masalah pemasaran yang dialami yaitu tekanan persaingan baik di pasar domestik dari produk yang serupa buatan sendiri dan impor, maupun di pasar internasional, dan kekurangan informasi yang akurat serta up to date mengenai peluang pasar di dalam maupun luar negeri.

2. Keterbatasan Finansial

Terdapat dua masalah utama dalam kegiatan UMKM di Indonesia, yakni dalam aspek finansial (mobilisasi modal awal dan akses ke modal kerja) dan financial jangka panjang untuk investasi yang sangat diperlukan demi pertumbuhan output jangka panjang. Walaupun pada umumnya modal awal bersumber dari modal (tabungan) sendiri atau sumber-sumber informal, namun sumbersumber permodalan ini sering tidak memadai dalam untuk kegiatan produksi maupun investasi. Walaupun begitu banyak skim-skim kredit dari perbankan dan bantuan Badan Usaha Milik Negara (BUMN), sumber pendanaan dari sektor informal masih tetap dominan dalam pembiayaan kegiatan UMKM. Hal ini disebabkan karena lokasi bank terlalu jauh bagi pengusaha yang tinggal di daerah, persyaratan terlalu berat, urusan administrasi yang rumit, dan kurang informasi mengenai skim-skim perkreditan yang ada beserta prosedurnya. Lagi pula, sistem pembukuan yang belum layak secara teknis perbankan menyebabkan UMKM juga sulit memperoleh kredit.

3. Keterbatasan SDM

Salah satu kendala serius bagi banyak UMKM di Indonesia adalah keterbatasan SDM terutama dalam aspek-aspek entrepreneurship, manajemen, teknik produksi, pengembangan produk, engineering design, quality control, organisasi bisnis, akuntansi, data processing, teknik pemasaran, dan penelitian pasar. Semua keahlian ini sangat dibutuhkan untuk mempertahankan atau memperbaiki kualitas produk, meningkatkan efisiensi dan produktivitas dalam produksi, memperluas pangsa pasar dan menembus pasar barang.

4. Masalah Bahan Baku

Keterbatasan bahan baku serta kesulitan dalam memperolehnya dapat menjadi salah satu kendala yang serius bagi pertumbuhan output ataupun kelangsungan produksi bagi banyak UMKM di Indonesia. Hal ini dapat disebabkan harga yang relative mahal. Banyak pengusaha yang terpaksa berhenti dari usaha dan berpindah profesi ke kegiatan ekonomi lainnya akibat masalah keterbatasan bahan baku.

5. Keterbatasan Teknologi

UMKM di Indonesia umumnya masih menggunakan teknologi yang tradisional, seperti mesin-mesin tua atau alat-alat produksi yang bersifat manual. Hal ini membuat produksi menjadi rendah, efisiensi menjadi kurang maksimal, dan kualitas produk relatif rendah.

6. Kemampuan Manajemen

Kekurangmampuan pengusaha kecil untuk menentukan pola manajemen yang sesuai dengan kebutuhan dan tahap pengembangan usahanya, membuat pengelolaan usaha menjadi terbatas. Dalam hal ini, manajemen merupakan seni 
yang dapat digunakan atau diterapkan alam penyelenggaraan kegiatan UMKM, baik unsur perencanaan, pelaksanaan, dan pengawasan.

7. Kemitraan

Kemitraan mengacu pada pengertian bekerja sama antara pengusaha dengan tingkatan yang berbeda yaitu antara pengusahakecil dan pengusaha besar. Istilah kemitraan sendiri mengandung arti walaupun tingkatannya berbeda, hubungan yang terjadi adalah hubungan yang setara (sebagai mitra kerja) ${ }^{27}$

Berdasarkan hasil wawancara dengan Ketua Komunitas Tangan Diatas (TDA) Kota Bima, Bapak Anang Zaini lokasi bertempat di Jl. RA Kartini 9 Paruga Kota Bima pada pukul 16:00 WIB, kendalanya dipicu oleh kurangnya penyuluhan di masyarakat tentang hubungannya terhadap perekonomian dan pentingnya berjiwa wirausaha sehingga pemikiran para sarjana muda cenderung instan dan memilih pekerjaan kantoran karena menganggap menjadi seorang pengusaha itu harus memulai dari nol. ${ }^{28}$

Sedangkan dari hasil penelitian yang dilakukan oleh peneliti terhadap Himpunan Pengusaha Muda Indonesia (HIPMI) dan Komunitas Tangan Diatas (TDA) ada beberapa kendala yang dihadapi oleh HIPMI dan TDA dalam mengurangi pengangguran terbuka di Kota Bima diantaranya adalah Masyarakat masih asing terhadap kedua komunitas tersebut sehingga mengakibatkan Kurangnya pemahaman serta tanda Tanya terhadap peran HIPMI dan TDA. ${ }^{29}$

\section{KESIMPULAN}

Dari hasil penelitian ini dapat ditarik kesimpulan yang berkaitan dengan peran pengusaha dalam mengurangi pengangguran terbuka dikota bima dan kendala yang yang hadapi pengusaha dalam mengatasi pengangguran adalah sebagai berikut:

1. Peran pengusaha dalam mengurangi pengangguran terbuka perspektif Ekonomi Islam di Kota Bima adalah dengan cara mendirkan hotel, café, dan jasa barbershop. Peran ini telah mengadopsi semangat Ekonomi Islam yang menghendaki setiap insan untuk produktif dan semangat dalam kemandirian.

2. dapat dilakukan secara langsung maupun tidak langsung. Untuk mengatasi pengangguran secara langsung pemerintah dapat langsung membuka lapangan kerja baik dibidang pemerintahan maupun perekonomian serta menciptakan proyek padat karya. Sedangkan cara tidak langsung yakni dengan memberikan bekal pengetahuan, keterampilan serta menumbuhkan sikap sebagai seorang pengusaha pada para pencari kerja melalui pengembangan kewirausahaan.

3. Kendala yang dihadapi oleh HIPMI dan TDA dalam mengurangi pengangguran terbuka di Kota Bima diantara adalah masyarakat masih asing terhadap kedua komunitas tersebut sehingga mengakibatkan Kurangnya pemahaman serta tanda tanya terhadap peran HIPMI dan TDA. Selain itu, karakter masayarakat yang berorientasi menjadi PNS dan kurang memiliki jiwa berwirausaha memperparah kendala yang dihadapi.

27 alfian arif adhiatma "Pengaruh Modal Awal, Lama Usaha, Dan Jam Kerja Terhadap Pendapatan Pedagang Kayu Glondong Di Kelurahan Karang Kebagusan Kabupaten Jepara", jurnal ekonomi, No 1, Volume 1 (juni 2005) 55

${ }^{28}$ Anang Zaini, wawancara, 7 juli 2020

${ }^{29}$ Zulkifli maman, wawancara, Kota Bima, 27 agustus 2020 


\section{DAFTAR PUSTAKA}

Abdurrahman, Nana Herdiana, Managemen Bisnis Syariah Dan Kewirausahaan, (bandung: cv pustaka setia, 20013).

Badan Pusat Statistik (BPS) Kota Bima, 23 maret 2020).

Hamdani, M., Entrepreneurship: kiat melihat dan memberdayakan potensi bisnis, (Yogyakarta: starbooks, 2014).

Harefa, Lola Imanda, "Analisis Program Kewirausahaan Himpunan Pengusaha Muda Indonsia (HIPMI) Dalam Meningkatkan Minat Berwirausaha Pemuda Di Kota Medan", ("skripsi", Sekolah Pascasarjan Universitas Sumatra Utara, Medan, 2018).

Idris, Amiruddin, Ekonomi Publik, (Yogyakarta: Deepublish, 2016).

Ismail, Kemiskinan Perspektif Ekonomi Islam, Jurnal Ekonomi Syariah (J-ESA), Volume 3, Nomor 1, Juni 2020

Kamus Besar Bahasa Indonesia (KBBI)

Noor, Juliansyah, Metodelogi Penelitian, (Jakarta: Kencana, 2011).

Probosiwi, Ratih, "Pengangguran Dan Pengaruhnya Terhadap Tingkat Kemiskinan", Jurnal Pks, No. 2, Volume 15 (Juni 2016).

Rusydi Ananda \& Tien Rafida, Pengantar Kewirausahaan: Rekayasa Akademik Melahirkan Enterpreneurship, (Medan: Perdana Publishing, 2016)

S, Mulyadi, Ekonomi Sumber daya Manusia dalam perspektif Pembangunan, (Jakarta: Rajawali Pres.2014).

Sugiyono, Metode Penelitian Kuantitatif KualitatifDan RED, (Bandung: alfabeta,Cv, 2011).

Sukidjo, "Peran Pengusaha Dalam Mengatasi Pengangguran Di Indonesia" jurnal ekonomi,No. 1, Volume 1 (agustus, 2005).

Wulandari, Sri, "peran badan perencanaan pembangunan daerah dalam pelaksanaan musrenbang di kota tarakan", ejournal administrasi Negara, No. 4, Volume 1, (November 2013)

Yunus, Islam dan Kewirausahaan Inovatif, (Malang: UIN-MALANG, 2008).

http://www.tangandiatas.com

https://id.m.wikipedia.org/wiki/Kota_Bima 